\section{Relay-cropping and Fallow Programs for Strawberry-based Production System: Effects on Crop Productivity and Weed Control}

\author{
Jialin Yu and Nathan S. Boyd ${ }^{1}$ \\ Department of Horticulture, Gulf Coast Research and Education Center, \\ University of Florida, Wimauma, FL 33598

\section{Zhengfei Guan} \\ Department of Food and Resource Economics, Gulf Coast Research and \\ Education Center, University of Florida, Wimauma, FL 33598
}

Additional index words. crop rotation, integrated weed management, plasticulture, relaycropping, multi-cropping

\begin{abstract}
Many strawberry growers in Florida relay crop vegetables with strawberries or grow multiple crops on the same plastic mulch. The practice can reduce the overall input costs per crop but weed management can be problematic. Field experiments designed as a split plot were conducted in Balm and Dover, FL over two successive strawberrygrowing seasons from Oct. 2014 to Mar. 2015 (year 1) and Oct. 2015 to Mar. 2016 (year 2) and two successive muskmelon-growing seasons from March to July 2015 (year 1) and March to July 2016 (year 2). The objectives were to examine the effect of summer fallow programs and the presence or absence of a relay-crop on weed density and strawberry (Fragaria Xananassa Duchesne) and muskmelon (Cucumis melo L.) yields. Summer fallow programs included leaving the plastic mulch in place and reusing it in year 2 , a sunn hemp (Crotalaria juncea $\mathrm{L}$.) cover crop, or a conventional chemical fallow. Relay cropping muskmelon with strawberries had no effect on strawberry yield. Summer fallow programs had no effect on muskmelon growth and yield in Balm and Dover, as well as strawberry growth and yield in Balm. In Dover, the plastic mulch summer fallow had $22 \%$ to $34 \%$ lower berry yield in year 2 compared with cover crop and chemical fallow, respectively. In year 2 , relay-cropping was more effective in reducing total weed density compared with strawberry monoculture in Dover but not in Balm. In year 2 in Dover, averaged overall summer fallow programs, the total weed density was $\approx$ 3-fold less in relay-cropping than strawberry monoculture. Of all the summer fallow programs evaluated, leaving the plastic mulch in place combined with glyphosate was the most effective summer fallow program, whereas the conventional chemical fallow was the least effective at weed suppression. We conclude that relay cropping or double use of plastic mulch for successive strawberry crops are viable options for Florida strawberry growers.
\end{abstract}

Florida is a principal producer of strawberry ( $F$. $\times$ ananassa Duchesne) in the United States. The state ranks second behind California in terms of total production, and during the 2015-16 growing season, a total of 108 million $\mathrm{kg}$ of strawberries were harvested from 4411 ha, producing a farm gate value of \$291 million (USDA-NASS, 2017). In recent years, the Florida strawberry industry has faced pressure from a 4-fold increase over 10 years (2004-14) in berry

Received for publication 31 Oct. 2017. Accepted for publication $28 \mathrm{Jan} .2018$.

This research was funded by the Specialty Crop Block Grant Program and the Florida Strawberry Research and Education Foundation.

We would like to thank the staff of Jaymar Produce and Brad Booker for assistance with crop production. We would also like to thank Mike Sweat, Nicole Billera, Hector Torres, Matthew Parks, and Radhika Rijal for their assistance.

${ }^{1}$ Corresponding author. E-mail: nsboyd@ufl.edu. and Reed, 2016; Nyoike and Liburd, 2013). Strawberry is one of the most expensive crops to produce due in part to the high costs of land preparation, fumigation, plastic mulch, transplants, fertigation, and pest management (Waterer et al., 2008; Whitaker et al., 2011).

One way to reduce production costs is to grow more than one crop on the same plastic mulch before its disposal. This approach distributes the input costs over multiple crops (Nyoike and Liburd, 2013; Santos et al., 2008) and may increase farm revenue and reduce farm income risk due to the diversification effect. This can be achieved by planting the second crop in the same field before (relay cropping) or after (multicropping) strawberry crop termination (Ngouajio and Ernest, 2005; Santos et al., 2008). Relaycropping on the same plastic mulch might be particularly beneficial to Florida growers because relatively warm weather and a long growing season makes it possible to grow two or more crops on the mulch within a single calendar year. In Florida, almost all of the strawberry production occurs in Hillsborough County. In this region, strawberries are typically planted between September and early October, and harvested from December through March or early April. Muskmelon (C. melo L.) is a short-season crop and can be planted in late spring or early summer in Florida. Growers frequently transplant muskmelon into strawberry beds that they are still harvesting. In early to mid-March the strawberries are removed by hand and the muskmelons are left to grow. The inclusion of relay-crops such as muskmelon in strawberrybased cropping system may have a positive or negative effect on summer annual weed management. On the one hand, relay-cropping limits the herbicides that can be used and provides a longer season for weeds to emerge in the transplant holes and in the row middles. On the other hand, leaving the plastic mulch in place for a longer period inhibits weed germination and could disrupt the life cycle of some species. To our knowledge, there are no studies that have examined the viability of the different fallow period treatments used by growers in the presence or absence of a relay-crop. The authors are also unaware of any published research that examines the effect of these unique cropping systems on weed density within the crop.

A wide variety of rotations and cover crops have been used to reduce weed (Adler and Chase, 2007; Cho et al., 2015; McSorley et al., 2008; Price and Norsworthy, 2013) and plant-parasitic nematode populations (Wang et al., 2002, 2006, 2007), and many of these, particularly legumes, increases soil fertility for the subsequent crops (Wang et al., 2006). Sunn hemp (C. juncea L.) is a legume cover crop and is thought to have important effects on weed population dynamics (Cho et al., 2015; McSorley et al., 2008; Price and Norsworthy, 2013). Sunn hemp establishes quickly and accumulates shoot biomass rapidly and is an excellent cover crop for weed suppression (Cho et al., 2015; 
McSorley et al., 2008; Mosjidis and Wehtje, 2011). Sunn hemp is low maintenance and requires no attention after planting until harvest (White and Haun, 1965). Moreover, integration of sunn hemp as a cover crop may reduce weed emergence and growth through release of allelochemicals (Adler and Chase, 2007; Javaid et al., 2015; Skinner et al., 2012). Therefore, the use of sunn hemp in a fallow period may shift the composition of weed seed bank and increase the crop productivity in a rotation program. To our knowledge, no studies have investigated the weed management effects associated with practical integration of sunn hemp into a strawberry rotation system.

The objectives of this research were 1) to evaluate the effect of relay cropping muskmelon with strawberry on strawberry yield or weed population dynamics, 2) to compare the effectiveness of sunn hemp cover crop and chemical fallow programs on the weed densities in the subsequent strawberry or muskmelon crop, and 3) to evaluate the effect of relay cropping 2-4 crops using the same plastic mulch on crop yields.

\section{Materials and Methods}

Experimental setup and treatments. Experiments were conducted from Oct. 2014 to July 2016 at the Gulf Coast Research and Education Center in Balm, FL $\left(27^{\circ} \mathrm{N}, 82^{\circ} \mathrm{W}\right)$ and at the Dover Research farm in Dover, FL $\left(28^{\circ} \mathrm{N}, 82^{\circ} \mathrm{W}\right)$. The soil type in Balm is a Myakka fine sand (Sandy, siliceous, hyperthermic Oxyaquic Alorthod) with a $\mathrm{pH}$ of 7.6 and $0.8 \%$ organic matter. The soil in Dover is a Seffner fine sand (Sandy, siliceous, hyperthermic Quartzipsammentic Haplumbrepts) with a $\mathrm{pH}$ of 7.6 and $<1 \%$ organic matter.

Raised beds were formed using bedpressing equipment (Kennco Manufacturing, Ruskin, FL) on 1.2-m centers, a height of $30.5 \mathrm{~cm}$, and a bed-top width of $66 \mathrm{~cm}$. A single drip tape with emitters every $30 \mathrm{~cm}$ and a flow rate of $0.95 \mathrm{~L} \cdot \mathrm{min}^{-1}$ per $30.5 \mathrm{~m}$ (Jain Irrigation, Inc., Haines City, FL) was installed in the center of the bed. The bed was covered with virtually impermeable film plastic mulch (Berry Plastics Corp., Evansville, IN). In year 1 , the beds were fumigated with $336 \mathrm{~kg} \cdot \mathrm{ha}^{-1}$ of $63.4 \%$ 1,3-dichloropropene + $34.7 \%$ chloropicrin (Telone C-35; Dow AgroSciences LLC, Indianapolis, IN) before transplanting strawberries. The fumigant was injected with a two-shank fumigation rig at a 20 -cm depth. In year 2 , metam potassium (K-Pam HL Amvec, Los Angeles, CA) was injected in all beds at $336 \mathrm{~kg} \cdot \mathrm{ha}^{-1}$ before transplanting strawberries.

The experiments were set up in split-plot with four blocks in Balm and Dover over two successive strawberry (cv. WinterStar ${ }^{\mathrm{TM}}$ )growing seasons from Oct. 2014 to Mar. 2015 (year 1) and Oct. 2015 to Mar. 2016 (year 2) and two successive muskmelon (cv. Athena)-growing seasons from March to July in 2015 (year 1) and March to July in 2016 (year 2). The main plot factor was summer fallow programs including 1) leaving raised plastic mulch covered beds in place from the previous strawberry crop and applying 1-2 applications of glyphosate, 2) removing the plastic mulch and applying 1-2 glyphosate (Roundup Pro; Monsanto Company, St. Louis, MO) applications as chemical fallow, and 3) a sunn hemp cover crop planted at 56 $\mathrm{kg} \cdot \mathrm{ha}^{-1}$ (Table 1). Main plot consisted of four $24 \mathrm{~m}$ long beds in Balm or $12 \mathrm{~m}$ long beds in Dover, and the subplots were four $12 \mathrm{~m}$ long beds in Balm and $6 \mathrm{~m}$ long beds in Dover. Two rows of strawberry plants were transplanted per bed in all plots with $38-\mathrm{cm}$ spacing between plants in mid October in 2014 and 2015. The subplot was the presence or absence of muskmelon as a relay-crop transplanted into the strawberry crop on 4 Mar. 2015 and 3 Mar. 2016 in Balm, and 3 Mar. 2015 and 2 Mar. 2016 in Dover. Sub-plots that were relay cropped with muskmelon contained 10 plants per plot transplanted between the strawberry plants in the center of the bed with $0.6 \mathrm{~m}$ between plants. The strawberry plants were removed by hand in late March both years. Irrigation, fertilization, insect and disease management, and harvest of muskmelons and berries were conducted in accordance with standard Florida farm practices (Mossler, 2015; Vallad et al., 2014).

Summer fallow preparation in plots where the plastic mulch was removed and the aboveground vegetation was desiccated with paraquat (Gramoxone SL 2.0; Syngenta Crop Protection, Inc., Greensboro, NC) at $0.84 \mathrm{~kg}$ a.i./ha. This was followed by removal of plastic mulch and disking the field twice before planting the cover crop. In the chemical fallow plots, glyphosate at $0.8 \mathrm{~kg}$ a.e. $/ \mathrm{ha}$ was applied when weed seedlings reached 5-10 $\mathrm{cm}$ heights. In the plots where the plastic was left intact over the 2 year period, paraquat and glyphosate were applied using the same rate and application frequency as the chemical fallow plots. In the cover crop plots, sunn hemp was seeded on 25 Mar. 2015 and 31 Mar. 2015 following the termination of the strawberry in Balm and Dover, respectively.

Data collection. Weeds present in two quadrats measuring $61 \times 71 \mathrm{~cm}$ randomly placed in each plot were counted. Weeds were counted in either strawberry or muskmelon-growing season on 29 Jan. 2015 (strawberry, year 1), 11 Dec. 2015, 29 Jan. 2016 (strawberry, year 2), and 5 May 2016 (muskmelon, year 2) in Balm, FL, and 29 Jan. 2015 (strawberry, year 1), 31 Mar. 2015 (muskmelon, year 1), 11 Dec. 2015, 10 Feb. 2016, 17 Feb. 2016 (strawberry, year 2), and 6 May 2016 (muskmelon, year 2) in Dover, FL. Strawberries were harvested twice per week from 8 Jan. 2015 to 5 Mar. 2015 in year 1 and from 17 Dec. 2015 to 17 Mar. 2016 in year 2 at Balm; and from 20 Jan. 2015 to 16 Mar. 2015 in year 1 and from 14 Jan. 2016 to 12 Mar. 2016 in year 2 at Dover. Strawberry cover was rated on 10 Dec. 2015 at Balm and 11 Dec. 2015 at Dover. Strawberry cover was rated on a percent scale where 0 represented no strawberry and 100 represented complete strawberry cover on the bed top. Strawberry heights were measured from crown to tip on 7 Dec. 2015 (year 2) at Balm, and 11 Dec. 2015 (year 2) at Dover. Ripened melons from each plot were harvested from early May to June, and counts and weights recorded at least once per week.

Statistical analysis. Data were subjected to analysis of variance in SAS (version 9.2; SAS Institute, Inc., Cary, NC) with Proc Mixed Procedure with block as the random factor, and year, cropping system, summer fallow as fixed factors. Data were checked for normality using residual and QQ plot. Equality of variances was checked using Levene's test. Logarithmic or square root transformation was used when needed to normalize the data. Nontransformed data are presented. Treatment means were separated using the least squares means statement in SAS with the Tukey adjustment at $P=0.05$. Data collected on multiple dates, such as berry and melon yields, were analyzed using the repeated statement.

\section{Results and Discussion}

Weed suppression. Weeds were counted in the strawberry crop in year 1 but the data are not presented due to a lack of weeds present at both locations. No broadleaf weeds were present in the muskmelon crop at Balm in year 1 but weeds did occur in the muskmelon crop at Dover but no treatment differences were observed in broadleaf or total weed density (Table 2). The lack of treatment differences in year 1 is not surprising given that treatments did not differ until the end of the first strawberry crop.

The total number of weeds present in the strawberry crop in year 2 at Dover was affected by the fallow program and the presence or absence of relay-cropping (Table 2). There were $78 \%$ to $80 \%$ fewer weeds in the strawberry crop where the plastic mulch was left intact or where a cover crop was grown during the fallow period compared with chemical fallow. In Balm, there were no significant differences but where the plastic mulches were left intact tended to have fewer purple nutsedge or total weeds than other fallow programs. The difference between sites can likely be explained by the reduced weed density observed at Balm vs. Dover. At Balm, purple nutsedge (Cyperus rotundus L.) was the predominate weed and cultivation breaks rhizomes and stimulates sprouting of dormant tubers (Taylorson, 1967). No cultivation occurred where the plastic mulch was left in place and any nutsedge that did emerge through the plastic was treated with glyphosate. At Dover, goosegrass was the predominate weed with patchy purple nutsedge and several broadleaf species also occurring. A glyphosate management program did not adequately control the weeds, and as a result, some seed production occurred which resulted in increased weeds present in the following strawberry crop. Despite the different weed spectrum between sites, the results consistently show that leaving the mulch in place 


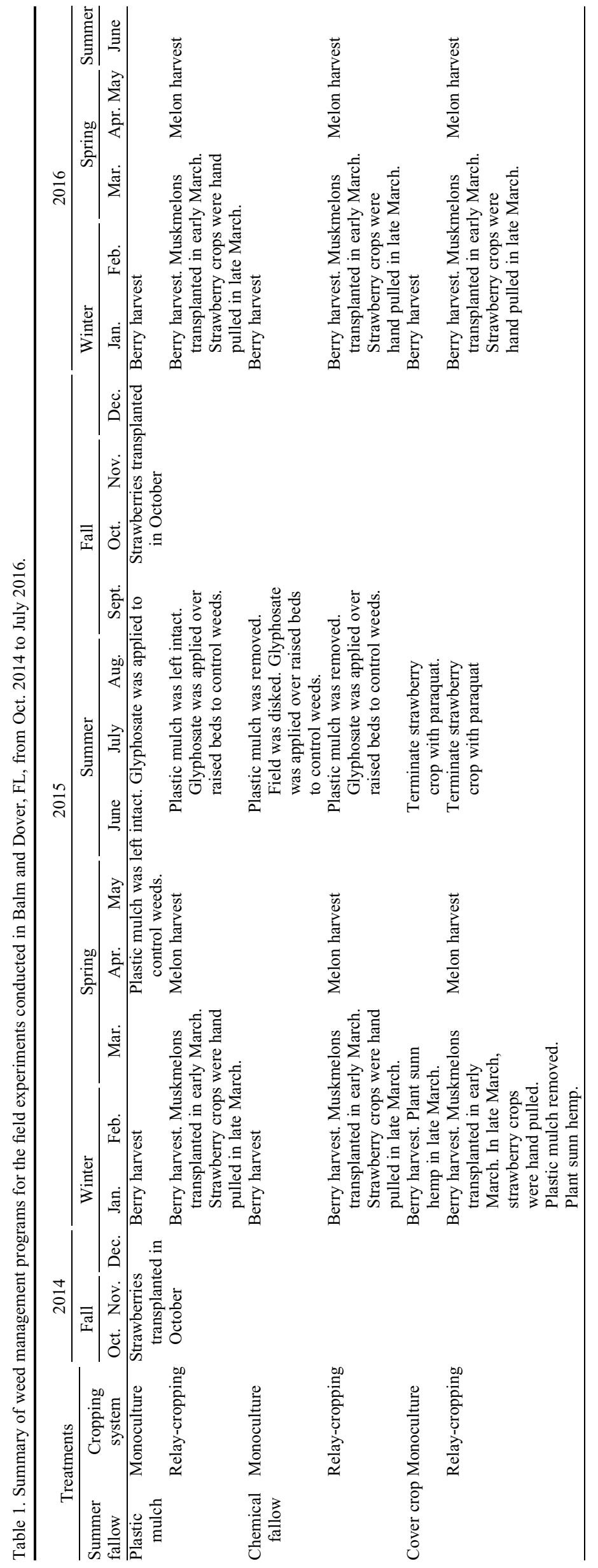

combined with glyphosate applications was an effective weed management tool.

There were $68 \%$ fewer weeds in the strawberry crop at Dover in year 2 where relay-cropping had occurred vs. plots with no relay-cropping. This is contrary to the common grower perception that weeds are more difficult to control when relay cropping. We hypothesize that there were fewer weeds in crops in the year following the relay-crop due to the shorter fallow period. When no relaycrop was grown, the fallow period was longer which provided a longer time frame for goosegrass to produce seed or nutsedge to produce additional tubers. This difference was not significant at Balm but the same trend was observed.

In Dover, in the strawberry crop in year 2, there was a significant interaction between the fallow program and the cropping system on nutsedge density (Table 3 ). Where the plastic mulch was left intact during the fallow period, there were fewer nutsedge than all other fallow programs regardless of the cropping system. There were $66 \%$ fewer weeds in the strawberry crop when a relaycrop was grown the preceding season followed by chemical fallow vs. a single crop followed by chemical fallow. This difference was not observed where a cover crop was grown. Combined, these results support our assertion that cultivation followed by glyphosate applications did not adequately control the weeds present and the situation was worse with a longer fallow period. Leaving the plastic mulch in place or growing a cover crop resulted in fewer weeds present in the subsequent strawberry crop. The same differences were also observed in the subsequent muskmelon crop.

Results show that plastic mulch was generally the most effective summer fallow program in maintaining weed suppression over growing seasons, whereas chemical fallow program was the least effective summer fallow program. This is not surprising given that plastic mulch effectively inhibits broadleaf weed density (Ashrafuzzaman et al., 2011; Johnson and Fennimore, 2005; Ngouajio and Ernest, 2005). Sunn hemp has been shown to effectively reduce weed populations in many studies (Adler and Chase, 2007; Cho et al., 2015; Javaid et al., 2015; McSorley et al, 2008; Skinner et al., 2012) but it did not have a consistent effect on weed density in the subsequent crop in our research. In Dover, the presence of sunn hump as a cover crop following muskmelon harvest may have effectively reduced establishment of the dominant weeds and prevented their seed production. In previous research, Sangakkara et al. (2006) noted that sunn hemp is beneficial in place of weedy fallows in tropical farming system, which provided more aboveground biomass and therefore, the greater weed suppression compared with Mexican sunflower (Tithonia diversifolia L.), Phaseolus beans, and a natural fallow.

Previous researchers noted that doublecropping with different planting timings and durations could be beneficial for managing 
Table 2. Number of broadleaf weeds and total weeds (broadleaf, grass, and nutsedge weeds) in strawberry monoculture and relay-cropping systems with different summer fallow programs in field experiments conducted in Balm and Dover, FL. ${ }^{z}$

\begin{tabular}{|c|c|c|c|c|c|c|c|c|}
\hline & \multirow{2}{*}{\multicolumn{2}{|c|}{$\begin{array}{c}\text { Broadleaf weeds }^{y} \\
\text { Dover }\end{array}$}} & \multicolumn{2}{|c|}{$\begin{array}{c}\text { Nutsedge } \\
\end{array}$} & \multicolumn{4}{|c|}{ Total weeds } \\
\hline & & & $\begin{array}{c}\text { Balm } \\
\begin{array}{c}\text { Strawberry } \\
\text { (yr 2) }\end{array}\end{array}$ & $\begin{array}{c}\text { Dover } \\
\begin{array}{c}\text { Muskmelon } \\
(\mathrm{yr} 1)\end{array}\end{array}$ & \multicolumn{2}{|c|}{ Balm } & \multicolumn{2}{|c|}{ Dover } \\
\hline Plastic mulch & 2.4 & 15.6 & 2.7 & 0.3 & 5.1 & 11.3 & 2.6 & $49.8 \mathrm{~b}$ \\
\hline Chemical fallow & 2.8 & 0.5 & 38.2 & 0 & 47.8 & 222 & 2.8 & $229.8 \mathrm{a}$ \\
\hline Cover crop & 3.6 & 1.8 & 62.7 & 2.5 & 78.4 & 208 & 6.1 & $44.1 \mathrm{~b}$ \\
\hline \multicolumn{9}{|l|}{ Cropping system } \\
\hline Summer fallow & 0.5213 & 0.2500 & 0.5321 & 0.0790 & 0.5664 & 0.1134 & 0.0768 & 0.0144 \\
\hline Cropping system & 0.5177 & 0.3834 & 0.9260 & 0.2916 & 0.9213 & 0.8936 & 0.2381 & 0.0274 \\
\hline Summer fallow $x$ & 0.6356 & 0.4649 & 0.5864 & 0.1851 & 0.5495 & 0.4133 & 0.1667 & 0.0927 \\
\hline
\end{tabular}

${ }^{\mathrm{z}}$ Least-squares means within columns followed by different letters are significantly different at the $0.05 P$ level.

${ }^{\mathrm{y}}$ Weeds were counted in either strawberry- or muskmelon- growing season on 29 Jan. 2015 (strawberry, year 1), 11 Dec. 2015,29 Jan. 2016 (strawberry, year 2), and 5 May 2016 (muskmelon, year 2) in Balm, FL, and 31 Mar. 2015 (muskmelon, year 1), 11 Dec. 2015, 10 Feb. 2016,17 Feb. 2016 (strawberry, year 2), and 6 May 2016 (muskmelon, year 2) in Dover, FL. Weeds were counted on 29 Jan. 2015 (strawberry, year 1) in Balm and Dover, FL, but the data are not included due to the lack of weeds present. All weeds present in two quadrats measuring $61 \times 71 \mathrm{~cm}$ randomly placed on the bed top in each plot were counted.

${ }^{\mathrm{x}}$ Weeds were counted in muskmelon- or strawberry-growing season.

Table 3. Number of nutsedge shoots and total weeds (broadleaf, grass, and nutsedge weeds) in strawberry monoculture and relay-cropping systems with different summer fallow programs in field experiments conducted in Dover, FL. ${ }^{2}$

\begin{tabular}{|c|c|c|c|}
\hline \multirow[b]{2}{*}{ Summer fallow } & \multirow[b]{2}{*}{ Cropping system } & Nutsedge $^{\mathrm{y}}$ & Total weed \\
\hline & & Strawberry $^{x}$ (yr 2) & Muskmelon (yr 2) \\
\hline Plastic mulch & $\begin{array}{l}\text { Monoculture } \\
\text { Relay-cronning }\end{array}$ & $0 \mathrm{c}$ & $27.3 \mathrm{~b}$ \\
\hline \multirow[t]{2}{*}{ Chemical fallow } & Monoculture & $78.2 \mathrm{a}$ & $143.3 \mathrm{a}$ \\
\hline & Relay-cropping & $26.5 \mathrm{~b}$ & $42.9 \mathrm{~b}$ \\
\hline \multirow[t]{2}{*}{ Cover crop } & Monoculture & $13.8 \mathrm{~b}$ & $31.5 \mathrm{~b}$ \\
\hline & Relay-cropping & $23.4 \mathrm{~b}$ & $41.9 \mathrm{~b}$ \\
\hline Summer fallow & & $<0.0001$ & $<0.0001$ \\
\hline Cropping system & & 0.1846 & 0.0160 \\
\hline $\begin{array}{l}\text { Summer fellow } \times \\
\text { cropping system }\end{array}$ & & 0.0431 & 0.0004 \\
\hline
\end{tabular}

${ }^{\mathrm{z}}$ Least-squares means within columns followed by different letters are significantly different at the 0.05 $P$ level.

${ }^{\mathrm{y}}$ Nutsedge shoots were counted in strawberry-growing season on 11 Dec. 2015, 10 Feb. 2016, and 17 Feb. 2016 in year 2; and total weeds were counted in muskmelon-growing season on 6 May 2016 in year 2. Weeds present in two quadrats measuring $61 \times 71 \mathrm{~cm}$ randomly placed on the bed top in each plot were counted.

${ }^{\mathrm{x}}$ Weeds were counted in muskmelon- or strawberry-growing season.

certain weeds. For example, the inclusion of beans (a relatively late-planted crop) reduced infestations of early-emerging weeds in a subsequent sugar beet (Beta vulgaris L.) crop, which is planted earlier in the spring (Dotzenko et al., 1969). In the Pacific Northwest, recommendations for controlling jointed goatgrass (Aegilops cylindrical L.) in winter wheat (Triticum aestivum L.) include growing a spring wheat crop in the crop rotation to reduce the soil weed seedbank (Walenta et al., 2002). Previous studies of the impacts of crop diversity on weed population dynamics have focused on crop rotations that occur over multiple years (Cardina et al., 2002; Liebman and Dyck, 1993; Liebman and Staver, 2001). The results of the present study suggest that diversification of a cropping system within a single year may enhance weed management in vegetable crops without reducing productivity.

Strawberry. There was no treatment by harvest date interactions in the repeated- measures analysis at either site, and as a result, only total berry yields are presented (Table 4). In general, fallow management and the presence or absence of a relay-crop had no effect on berry yield. Relay-cropping had no effect on strawberry cover, strawberry height, or total berry yield in either location. We conclude that transplanting muskmelon into an established strawberry crop did not reduce yield. The one exception was significantly reduced berry yields following summer fallow programs where the plastic mulch was left intact in year 2 in Dover $(P=$ $0.0003)$. We postulated that the reduced berry yield compared with chemical fallow and cover crop in year 2 in Dover might be partially associated with reduced soil warming ability of plastic mulch. In previous research, Ngouajio and Ernest (2005) reported that weathering affected plastic mulches in a tomato (Lycopersicon esculentum Mill.) and cucumber (Cucumis sativus L.) double-cropping system. The authors noted that the optical and thermal properties of the mulches in the second year of doublecropping are affected, resulting in a reduced soil warming ability. Additional research is needed to determine how yield loss when growing multiple strawberry crops on the same mulch can be overcome.

Muskmelon. Treatment by harvest date interaction in the repeated-measures analysis was not significant for muskmelon yield in either location in either year, and thus, data are presented as total seasonal yield (Table 5). The main effect of summer fallow was not significant for muskmelon total fruit number and yield in either location in either year. These findings suggest that the evaluated summer fallow programs did not influence muskmelon growth and yield.

\section{Conclusions}

In summary, we evaluated alternative cropping systems that facilitate the production of two crops on the same plastic mulch within a single year (muskmelon relay cropped with strawberry), the production of two crops on the same plastic mulch over 2 years (two strawberry crops with the plastic mulch left in place during the fallow period), or four crops on the same plastic mulch over 2 years (muskmelon relay cropped with strawberry 2 years in a row with the plastic mulch left in place during the fallow period). Relaycropping did not reduce berry or melon yields and is likely to reduce input costs per crop compared with the standard practice of producing a single crop on a raised bed. The reduction in input costs would be a result of reduction of the required soil preparation between crops and repeated use of the same plastic mulch and drip tape. Summer fallow programs affected weed density in subsequent crops. The use of the same plastic mulch over two seasons combined with glyphosate was the most effective fallow program, whereas chemical fallow was the least effective at weed suppression. It is 
Table 4. Strawberry cover, height, and season total berry yield in strawberry monoculture or relay-cropping with different summer fallow programs in Balm and Dover, FL. ${ }^{z}$

\begin{tabular}{|c|c|c|c|c|c|c|c|c|}
\hline & \multicolumn{4}{|c|}{ Balm } & \multicolumn{4}{|c|}{ Dover } \\
\hline & \multirow{2}{*}{$\frac{\text { Cover }^{y}(\%)}{\text { Yr } 2}$} & \multirow{2}{*}{$\frac{\mathrm{Ht}(\mathrm{cm})}{\text { Yr } 2}$} & \multicolumn{2}{|c|}{ Yield $\left(\mathrm{kg} \cdot \mathrm{ha}^{-1}\right)$} & \multirow{2}{*}{$\frac{\text { Cover }(\%)}{\text { Yr } 2}$} & \multirow{2}{*}{$\frac{\mathrm{Ht}(\mathrm{cm})}{\mathrm{Yr} 2}$} & \multicolumn{2}{|c|}{ Yield $\left(\mathrm{kg} \cdot \mathrm{ha}^{-1}\right)$} \\
\hline & & & Yr 1 & Yr 2 & & & Yr 1 & Yr 2 \\
\hline \multicolumn{9}{|l|}{ Summer fallow } \\
\hline Chemical fallow & 28.7 & 22.1 & 23,498 & 27,782 & 30.7 & 23.7 & 21,715 & $12,358 \mathrm{a}$ \\
\hline Cover crop & 33.2 & 21.8 & 23,080 & 25,233 & 29.5 & 23.5 & 21,721 & $14,608 \mathrm{a}$ \\
\hline \multicolumn{9}{|l|}{ Cropping system } \\
\hline Monoculture & 30.2 & 22.1 & 24,352 & 26,240 & 27.5 & 23 & 21,565 & 11,434 \\
\hline Summer fallow & 0.1461 & 0.5381 & 0.3631 & 0.3121 & 0.1238 & 0.0802 & 0.9856 & 0.0003 \\
\hline Cropping system & 0.2909 & 0.9560 & 0.9096 & 0.8525 & 0.8087 & 0.6743 & 0.5328 & 0.0585 \\
\hline $\begin{array}{l}\text { Summer fallow } \times \\
\text { cropping system }\end{array}$ & 0.9506 & 0.2902 & 0.5983 & 0.5995 & 0.3910 & 0.4693 & 0.9904 & 0.0909 \\
\hline
\end{tabular}

${ }^{\mathrm{z}}$ Least-squares means within columns followed by different letters are significantly different at the $0.05 P$ level.

${ }^{\mathrm{y}}$ Strawberry covers were measured on 10 Dec. 2015 in Balm and 11 Dec. 2015 in Dover. Strawberry heights were measured on 7 Dec. 2015 in Balm, and 11 Dec. 2015 in Dover.

Strawberries were harvested twice per week from 8 Jan. 2015 to 5 Mar. 2015 (year 1) and from 17 Dec. 2015 to 17 Mar. 2016 (year 2) in Balm; and from 20 Jan. 2015 to 16 Mar. 2015 (year 1) and from 14 Jan. 2016 to 12 Mar. 2016 (year 2) in Dover.

Table 5. Muskmelon count and season total yield in strawberry monoculture or relay-cropping with different summer fallow programs in Balm and Dover, FL.

\begin{tabular}{|c|c|c|c|c|c|c|c|c|}
\hline \multirow{2}{*}{ Summer fallow } & \multicolumn{4}{|c|}{ Balm } & \multicolumn{4}{|c|}{ Dover } \\
\hline & \multicolumn{2}{|c|}{ Count (no./ha) } & \multicolumn{2}{|c|}{ Yield $\left(\mathrm{kg} \cdot \mathrm{ha}^{-1}\right)$} & \multicolumn{2}{|c|}{ Count (no./ha) } & \multicolumn{2}{|c|}{ Yield $\left(\mathrm{kg} \cdot \mathrm{ha}^{-1}\right)$} \\
\hline Plastic mulch & 1,177 & 6,643 & 1,186 & 11,614 & 4,204 & 1,093 & 8,093 & 1,575 \\
\hline Cover crop & 1,051 & 5,424 & 1,108 & 9,668 & 3,573 & 1,345 & 6,800 & 2,071 \\
\hline$P$ value & 0.4123 & 0.5563 & 0.5334 & 0.6663 & 0.6411 & 0.2404 & 0.1699 & 0.1199 \\
\hline
\end{tabular}

important to note that leaving the plastic mulch in place during the fallow period did not result in reduced yields in year 2 at one site. Further research is needed to determine if there is an economic benefit to this practice even when reduced yields occur. We conclude that relay-cropping or double use of plastic mulch for successive strawberry crops are viable options for Florida strawberry growers.

\section{Literature Cited}

Adler, M.J. and C.A. Chase. 2007. Comparison of the allelopathic potential of leguminous summer cover crops: Cowpea, sunn hemp, and velvetbean. HortScience 42:289-293.

Anikwe, M., C. Mbah, P. Ezeaku, and V. Onyia. 2007. Tillage and plastic mulch effects on soil properties and growth and yield of cocoyam (Colocasia esculenta) on an ultisol in southeastern Nigeria. Soil Tillage Res. 93:264272.

Ashrafuzzaman, M., M.A. Halim, M.R. Ismail, S. Shahidullah, and M.A. Hossain. 2011. Effect of plastic mulch on growth and yield of chilli (Capsicum annuum L.). Braz. Arch. Biol. Technol. 54:321-330.

Boyd, N.S. and T. Reed. 2016. Strawberry tolerance to bed-top and drip-applied preemergence herbicides. Weed Technol. 30:492-498.

Cardina, J., C.P. Herms, and D.J. Doohan. 2002. Crop rotation and tillage system effects on weed seedbanks. Weed Sci. 50:448-460.

Cho, A.H., C.A. Chase, D.D. Treadwell, R.L. Koenig, J.B. Morris, and J.P. Morales-Payan. 2015. Apical dominance and planting density effects on weed suppression by sunn hemp
(Crotalaria juncea L.). HortScience 50:263267.

Dotzenko, A., M. Ozkan, and K. Storer. 1969. Influence of crop sequence, nitrogen fertilizer and herbicides on weed seed populations in sugar beet fields. Agron. J. 61:34-37.

Hou, X., F. Wang, J. Han, S. Kang, and S. Feng. 2010. Duration of plastic mulch for potato growth under drip irrigation in an arid region of Northwest China. Agr. For. Meteorol. 150:115-121.

Javaid, M.M., M. Bhan, J.V. Johnson, B. Rathinasabapathi, and C.A. Chase. 2015. Biological and chemical characterizations of allelopathic potential of diverse accessions of the cover crop sunn Hemp. J. Amer. Soc. Hort. Sci. 140:532-541.

Johnson, M.S. and S.A. Fennimore. 2005. Weed and crop response to colored plastic mulches in strawberry production. HortScience 40:13711375.

Lament, W.J. 1993. Plastic mulches for the production of vegetable crops. HortTechnology 3:35-39.

Liebman, M. and E. Dyck. 1993. Crop rotation and intercropping strategies for weed management. Ecol. Appl. 3:92-122.

Liebman, M. and C.P. Staver. 2001, Crop diversification for weed management, p. 322-374. In: M Liebman, C.L. Mohler, and C.P. Staver (eds.). Ecological management of agricultural weeds. Cambridge Univ. Press, Cambridge, UK.

McSorley, R., K. Wang, and J. Frederick. 2008. Integrated effects of solarization, sunn hemp cover crop, and amendment on nematodes, weeds, and pepper yields. Nematropica 38:115-126.

Mosjidis, J.A. and G. Wehtje. 2011. Weed control in sunn hemp and its ability to suppress weed growth. Crop Prot. 30:70-73.
Mossler, M. 2015. Florida crop/pest management profile: Muskmelon. Univ. Florida, IFAS, Gainesville, FL. 16 Aug. 2017. <http://edis.ifas.ufl.edu/ pi047>.

Ngouajio, M. and J. Ernest. 2005. Changes in the physical, optical, and thermal properties of polyethylene mulches during double cropping. HortScience 40:94-97.

Nyoike, T.W. and O.E. Liburd. 2013. Effect of Tetranychus urticae (Acari: Tetranychidae), on marketable yields of field-grown strawberries in North-Central Florida. J. Econ. Entomol. 106:1757-1766.

Price, A.J. and J.K. Norsworthy. 2013. Cover crops for weed management in southern reducedtillage vegetable cropping systems. Weed Technol. 27:212-217.

Sangakkara, U., P. Bandaranayake, D. Weerasekera, and P. Stamp. 2006. Interseasonal cropping Its potential for managing weeds in the Asian tropics. J. Plant Dis. Prot. 20:921927.

Santos, B.M., C.E. Esmel, S. Slamova, and E.A. Golden. 2008. Optimum planting dates for intercropping cucumber, squash, and muskmelon with strawberry. HortTechnology 18:656-659.

Skinner, E.M., J.C. Díaz-Pérez, S.C. Phatak, H.H. Schomberg, and W. Vencill. 2012. Allelopathic effects of sunnhemp (Crotalaria juncea L.) on germination of vegetables and weeds. HortScience 47:138-142.

Suh, D.H., Z. Guan, and H. Khachatryan. 2017. The impact of Mexican competition on the U.S. strawberry industry. Intl. Food Agribus. Mgt. Rev. 20:591-604.

Taylorson, R. 1967. Seasonal variation in sprouting and available carbohydrate in yellow nutsedge tubers. Weeds 15:22-24. 
USDA-NASS. 2017. United States Department of Agriculture. National Agricultural Statistical Service. 22 Oct. 2017. <https://www.usda. gov/wps/portal/usda/usdahome $>$.

Vallad, G.E., J. Freeman, and P.J. Dittmar. 2014. Vegetable and small fruit production handbook of Florida 2014-2015. Univ. Florida, Gainesville, FL.

Walenta, D.L., J.P. Yenish, F.L. Young, and D.A Ball. 2002. Vernalization response of plants grown from spikelets of spring and fall cohorts of jointed goatgrass. Weed Sci. 50:461-465.
Wang, K., R. McSorley, A. Marshall, and R. Gallaher. 2006. Influence of organic Crotalaria juncea hay and ammonium nitrate fertilizers on soil nematode communities. Appl. Soil Ecol. 31:186198.

Wang, K., B. Sipes, and D. Schmitt. 2002. Crotalaria as a cover crop for nematode management: A review. Nematropica 32:35-58.

Wang, Q., Y. Li, Z. Handoo, and W. Klassen. 2007. Influence of cover crops on populations of soil nematodes. Nematropica 37:79-92.
Waterer, D., W. Hrycan, and T. Simms. 2008. Potential to double-crop plastic mulch. Can. J. Plant Sci. 88:187-193.

Whitaker, V.M., N.S. Boyd, N.A. Peres, and H.A. Smith. 2011. Strawberry production in Florida Hort. Sci. Dept. Document HS736, Univ. Florida, IFAS and Florida Coop. Ext. Serv. <http:// edis.ifas.ufl.edu/pdffiles/cv/cv13400.pdf $>$.

White, G.A. and J. Haun. 1965. Growing Crotalaria juncea, a multi-purpose legume, for paper pulp. Econ. Bot. 19:175-183. 